
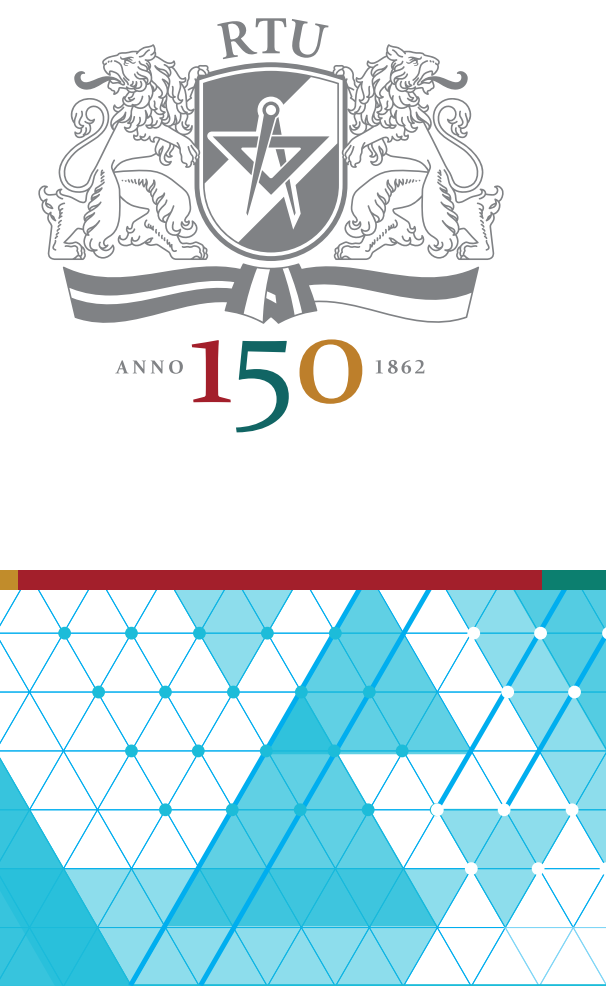

11-12 October 2012, Riga

Riga Technical University 53rd International Scientific Conference

Dedicated to the $150^{\text {th }}$ Anniversary and The 1 st Congress of World Engineers and Riga Polytechnical Institute / RTU Alumni

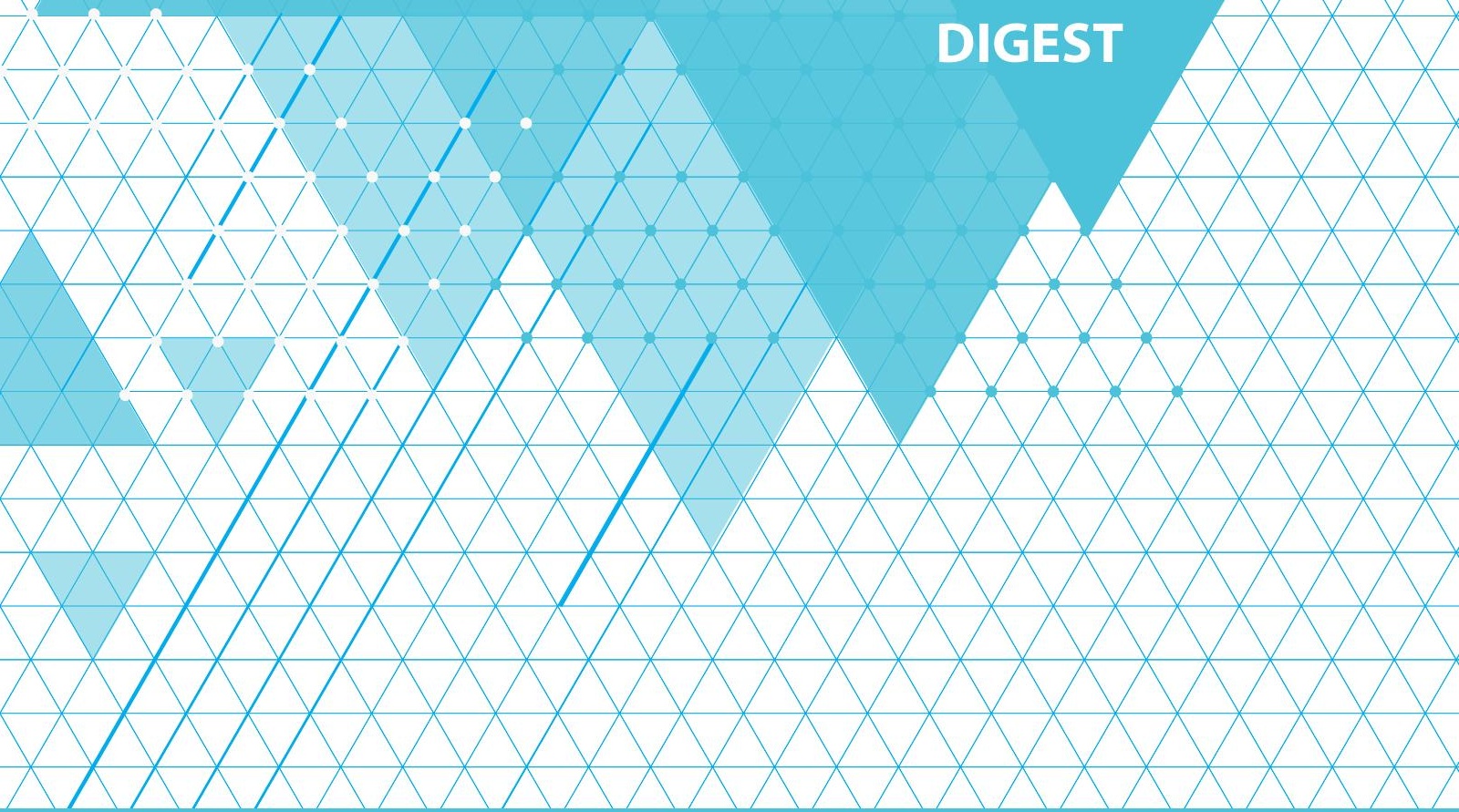




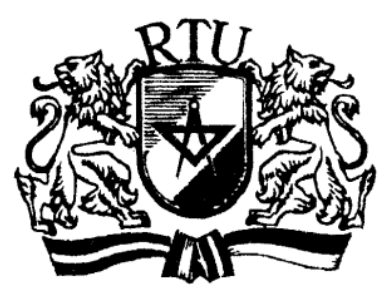

\section{RIGA TECHINICAL UNIVERSITY $53^{\text {rd }}$ INTERNATIONAL SCIENTIFIC CONFERENCE DEDICATED TO THE $150^{\text {th }}$ ANNIVERSARY AND THE $1^{\text {st }}$ CONGRESS OF WORLD ENGINEERS AND RIGA POLYTECHINICAL INSTITUTE / RTU ALUMINI}

11-12 October 2012

Rīga, Latvija 


\title{
Novel Concepts of "Niche-Relief" and "Niche- Voltage" for Stem Cells as a Base of Bone and Hematopoietic Tissues Biomimetic Engineering
}

\author{
Igor Khlusov (Siberian State Medical University, Tomsk, Russia), Yuri Dekhtyar (Riga Technical University, Riga, \\ Latvia), Marina Khlusova (Siberian State Medical University, Tomsk, Russia), Eduard Gostischev (Tomsk \\ Polytechnic University, Tomsk, Russia), Yuri Sharkeev (Institute of Strength Physics and Materials Science, Tomsk, \\ Russia), Vladimir Pichugin (Tomsk Polytechnic University, Tomsk, Russia), Elena Legostaeva (Institute of Strength \\ Physics and Materials Science, Tomsk, Russia)
}

\begin{abstract}
Keywords - calcium phosphate coatings, artificial microterritories, cell culture, mice, electron work function.

\section{INTRODUCTION}

Currently, a lot of publications, mainly as hypotheses, were dedicated to niches for hemopoietic stem cells (HSC). Multipotent mesenchymal stromal cells (MMSC) are treated as important cell component of HSC niches [1].

At the same time, the circumstance that discussion of existence of niches determining fate of MMSC themselves just appears in literature sets at gaze [2]. Pilot experimental data about existence and dimensions of niches for osteogenic differentiation of MMSC, their close dependence on quantitative variables of bone mineral substance relief were recently obtained by us [3].

In this connection, investigation of the relief features effects of model mineral matrix on structural-functional conditions of human MMSC and remodeling of bone/bone marrow system in mice was of great interest.
\end{abstract}

\section{SPECIMENS PREPARATION}

\section{A. Materials}

Pure titanium specimens (diameter $12 \mathrm{~mm}$, thickness $1 \mathrm{~mm}$ ) with bilateral calcium phosphate $(\mathrm{CP})$ coatings were used as artificial substrate for MMSC cultivation. Coatings were applied on titanium by means of micro-arc oxidation method in $10 \%$ phosphoric acid solution containing suspension of nano-sized $(20-40 \mathrm{~nm})$ synthetic HAP particles.

Morphology of CP coatings was estimated by Quanta 200 ESEM FEG scanning electronic microscope (SEM). Roughness of CP coatings was evaluated by means of Talysurf 5-120 measuring system (Taylor-Hobson, UK). Ra $(\mu \mathrm{m})$ index was determined.

Alterations of electron work function $(\varphi)$ and voltage distribution over the specimens' surface were carried out as described earlier.

\section{B. Cell Techniques}

Culture of human prenatal stromal lung cells ("Stem cells bank" Co Ltd., Tomsk) as MMSC source was studied on pure titanium discs with $\mathrm{CP}$ coating in 4 days after implants addition into culture medium.

Computer morphometry was applied for detection of quantity levels of cellular alkaline phosphatase (ALP) activity. Concentrations of calcium and inorganic phosphorus, ALP activities in supernatants were estimated according to standard colorimetric method. Osteocalcin (OC) levels were measured in cell supernatants by "sandwich" ELISA.

Technique of subcutaneous heterotopic osteogenesis in mice from column of syngeneic bone marrow, preliminary applied on CP surfaces was carried out as early described.
Statistical analysis was made by means of variation statistics methods with the use of Mann-Whitney U-test.

\section{RESUlts}

Implants with rough $\mathrm{CP}$ coatings have structural-functional sites (micro-regions) named "niches-relief" which are necessary for in vitro maturation and differentiation of HLPSC into secreting osteoblasts. ALP stained cells (osteoblast' marker) populated sockets of artificial surface. The ratio of area of ALP stained cell to artificial surface area occupied with stained cell was calculated. $\mathrm{S}_{\mathrm{ALP}} /$ Sniche index has been established to correlate with $\mathrm{CP}$ roughness index $\mathrm{Ra}$. Obviously, artificial "niches" for induction of MMSC osteogenic differentiation are a structural-functional concept.

These data allowed us to propose "niche-relief" conception for osteogenic differentiation and maturation of MMSC.

Maximal remodeling of mouse bone/bone marrow system in 45-day subcutaneous heterotopic test in vivo is also noted under optimal parameter (average index of cellular ALP area to artificial micro-region area is about $43 \%$ ) of osteogenic niche in vitro.

Probable physical mechanism of osteogenic niche functioning has been determined.

Our scientific team designed the device for electrostatic potential measurement of low-charged surfaces by means of M. Eguchi method developed. Work area of elevating electrode is 20 square millimeters. CP electrets demonstrated negative charge of surface electrostatic voltage with an average range of $45 \mathrm{mV}$.

A direct electrostatic interaction is considered as predictor of cells adhesion to implants. For all this, osteogenic cells have been known to migrate to cathode in electrostatic field. So, it can promote stem cell seeding and spreading.

Logarithmic interconnection of irregularities of $\mathrm{CP}$ coatings nanorelief and voltage estimated from the electron work function measurements was established. Increasing electron work function $(\varphi)$ and negative charge amplitude in the sockets (artificial "niches") of CP coatings nanorelief were observed. It can promote stem cell osteogenic differentiation.

"Niche-voltage" concept for biomimetic engineering of bone and bone marrow tissues was proposed.

\section{REFERENCES}

[1] Jing D, Fonseca A-V, Alakel N et al. (2010) Hematopoietic stem cells in co-culture with mesenchemal stromal cells - modeling the niche compartments in vitro. Haematologica 95:542-550.

[2] Kolf CM, Cho E, Tuan RS (2007) Mesenchemal stromal cells. Biology of adult mesenchymal stem cells: regulation of niche, self-renewal and differentiation. Arthritis Res Ther 9: 204-219.

[3] Khlusov IA, Khlusova MYu, Zaitsev KV et al. (2011) Pilot in vitro study of the parameters of artificial niche for osteogenic differentiation of human stromal stem cell pool. Bull Exp Biol Med 150(4):535-542. 